\title{
SME Loan Process Efficiency With McKinsey 7S Model
}

\author{
Diona Ayu Melinda, Andriyanti Wagianto*
}

\author{
Magister of Accounting, Universitas Indonesia, Salemba, Indonesia \\ *Corresponding author. Email: andriwagianto@gmail.com
}

\begin{abstract}
The rapid growth in fintech (financial technologies) companies is resulting in tougher competition in the banking industry. That is why banks should begin to improve their business model to meet the needs of borrowers. The objective of this paper is to evaluate the process of lending to borrowers and gives suggestion to improve the process. This research used a mixed method. The research instruments used are questionnaire, observation, and interview. The result from this research is banks should consider using advanced technology to improve their lending process, thus reducing processing time. In addition, because there are still many manual processes, banks should manage their human capital aspects, including improving their skills and competencies. For the conclusion, which can be seen from McKinsey's 7S elements, the systems and staffs are the elements that must be improved but the improvement of those elements must be in line with other elements.
\end{abstract}

Keywords: Bank, Efficiency, Loan Documentation, McKinsey 7S, Non-Value-Added.

\section{INTRODUCTION}

The development of technology in the current era is very rapid, which can be seen from one of the developments in the financial service providers such as fintech (financial technology). From 2017 to April 2019, 106 fintech companies were registered in OJK (Otoritas Jasa Keuangan 2019). Thus, banks must immediately make improvements in their workflow, especially for their internal processes. Without any improvement, it will likely result in loss, such as loss of customers due to customer dissatisfaction, increase the cost of processing loans, increased rework, and less productive employees (Pindyck \& Rubinfeld 2013). Thus, the current technological development is one of the items that must be considered for PT X in conducting business, especially the lending business line.

One problem that occurs in PT X is inefficiency in the workflow that can be seen from low productivity of loan staff, which is eleven times lower than the best practices, benchmark and loan analyst, which is eight times lower than best practices benchmark, based on internal data from the consulting company report. The scope to be discussed in this study is only related to the staff for loan disbursement and loan documentation because the productivity is lower than the loan analyst staff.

This research was motivated by a study that analyzed the causes of low productivity in a bank in India (Ramcharran 2017). That research used a quantitative approach, so the result could not provide deep suggestions such as using a mixed methodology (Schonfeld \& Farrell 2010). In addition, that research did not discuss the detailed process of loan disbursement and loan documentation. Thus, this paper discusses more deeply the problems that occur at PT $\mathrm{X}$, so that it can provide suggestions for PT $\mathrm{X}$ as well as other banks.

Other research using the McKinsey 7S model has been carried out, but it still has limitations where the object of research is only one field, a library (Cox 2018). For this reason, this paper aims to fill the gap, so that the use of this model can also be applied in the financial service sector.

This research required a deep understanding, not only limited to understanding a concept but also understanding 
the problem so that we can provide solutions and draw a conclusion (Ellet 2007). For this reason, this study was conducted to contribute in the form of suggestions for PT $\mathrm{X}$ related to the efficiency of loan process using McKinsey 7S model, so PT $X$ could increase its competitiveness.

There are two contributions from this study. First, it is expected that the banks can see their detailed internal processes, especially in providing loans to SME borrowers, because the competition for this industry has been very intense, which can be seen from the rapid increase of fintech companies. Thus, if banks do not improve their internal process, they will lose their customers and finally they will lose in competition. Second, for academics, the existence of this research is expected to be able to contribute for enriching science in the banking industry, where, at this time, research on banking still has not seen in depth the problems faced by loan division, especially in disbursement and documentation process. Thus, this paper help to cover that area, so the gap can be minimized.

Therefore, the research questions for this study are:

RQ 1: Why is the loan documentation process in PT X inefficient?

RQ 2: How can the problems that occur in PT $\mathrm{X}$ be overcome using the McKinsey $7 \mathrm{~S}$ model?

The purpose of this research is to evaluate the loan documentation process in PT $\mathrm{X}$ and give suggestions to PT $X$, so it can improve the loan processing time. The methodology in this paper is a mixed method, using an online survey, observation, and interview as research instruments. The online survey was used to understand the reasons inefficiency happens in PT X. Observation were used to observe the situation in PT X and capture the real condition about what happens in the loan unit. An interview was used to confirm the problems that occur in PT X.

This paper begins with a literature review (Section 2). Then, there is an explanation of the methodology and research instrument used in this study (Section 3). After that, the findings and results of the research are discussed (Section 4). Finally, the paper closes with conclusions (Section 5).

\section{LITERATURE REVIEW}

\subsection{Contingency Theory}

In contingency theory, it is stated that there is no best way to manage a company, either to lead the company or to make a decision, but internal and external factors can influence work processes and decision-making processes within the company (Otley 1980).

One problem that occurs in PT X is the existence of an inefficient loan process to borrowers, where this can be seen in the data described above. Therefore, this research aims to provide suggestions on how to provide loan efficiently and effectively without ignoring risk factors. This theory is used as the main foundation in practice, especially in making business decisions when companies must consider many factors, including risks and benefits that will be obtained from the decisions taken.

\subsection{McKinsey 7S Model}

McKinsey's 7S model is used to diagnose and solve problems that exist within a company, where this model is not only done by reorganizing the structure but also other related factors. There are seven main focuses: structure, strategy, system, style, staff, skills, and shared values (Waterman, Peters, \& Phillips 1980). To be able to run well, the seven dimensions must be interrelated.

\subsection{Efficiency}

A previous study explained what factors should be a concern to a company so that the workflow will become more efficient, which in turn will have an impact on reducing costs and increase firm's profit (Kaplan \& Cooper 1998).

In addition, other studies state that efficiency focuses more on two items. The first one is how to manage the resources that are owned so that it can produce as much output as possible. Second, a firm should focus on how to minimize costs in daily activities (Nicholson 2003).

\subsection{Non-Value-Added-Activity}

Non-value-added activity is any activity that does not provide value for internal and external consumers (Hansen \& Mowen 2015). This means that every internal process within the company should eliminate activities that do not provide value. This is because, if these activities are not eliminated, they will increase the costs of the company.

In previous studies, regarding the reduction of the level of waiting time for commercial banks, indicate that banks must be able to improve the quality and speed of their work in order to compete and be able to increase returns to shareholders (Gao 2016). 


\section{RESEARCH METHOD}

\subsection{Research Strategy}

This research was conducted by exploring the phenomena that occurred in PT X in detail. In addition, it can be used to answer the research questions described above. This study allowed us to know more about what factors make the process of lending at PT X inefficient so we could provide suggestions to PT X.

Besides this approach, this research can focus more on contemporary phenomena that are in line with real life (Yin 2008). Thus, this approach describes the problems that really happen and can provide solutions to existing problems that can be used by PT X and similar companies in dealing with problems regarding the loan process. Thus, the case study approach was more relevant for examining the problems described above.

\subsection{Research Method}

This study used mixed methods, i.e. a mixture of quantitative and qualitative methods (Tassakhori \& Creswell 2008). This method was used by researchers because it can produce richer research, add more data collection methods, make researchers more confident about the results of their research, is more integrated with theory, and can provide assurance to answer research questions (Jick 1979).

In addition, the use of this method is more likely for researchers to confirm existing data, develop an analysis of existing problems, and can generate new thinking by combining the data (Rossman \& Wilson 1985). In addition, this mixed method is still very rarely used in research, where, based on research conducted from 1988 to 2003 , only $1 \%$ of studies used this mixed method, even though by using this method the results obtained can be more informative, richer, and more useful for making a decision (Parker 2005). This mixed method was used for data collection, through interviews, surveys, observation (Denzin 1978).

Then, the methodology used was sequential triangulation, i.e. doing quantitative analysis first, and then qualitative analysis, because the sample used was the same person, so it would be more appropriate to do this method (Morse 1991).

\section{Research Instruments}

The research instruments used in this research are surveys, interviews, and observations. The selected respondents were managers and staff at PT X and were chosen based on the researchers' consideration that the managers and staff at PT X were more aware of the situation that occurs. This survey was conducted through online surveys and sent via the media WA (WhatsApp).

This interview was conducted face to face directly with the respondent. Observation was also needed by the researcher to know directly about PT X's field conditions in terms of employee management and loan document management work system so that we could answer why the loan process at PT X is inefficient.

\subsection{Data Analysis}

For data analysis, researchers used the content analysis and thematic analysis method in analyzing the data that were obtained previously by coding qualitative data into a quantitative form using NVIVO 12 Pro software, as well as descriptive analysis in order to provide a deeper description of the loan process at PT $\mathrm{X}$ as well as recommendations related to the work process at PT X.

\section{RESULTS AND DISCUSSION}

This section presents the answers to the research questions described above and provides recommendations to PT X so that the loan process in PT X can be more efficient.

\subsection{Survey}

The survey data were analyzed using content analysis. The survey was conducted in the form of open-ended questions with 30 employees at PT $X$, but the data received were 19 , thus the response rate was $63 \%$. This response rate is sufficient because the data obtained were already saturated.

Based on survey data processing using the word frequency in the NVIVO 12 Pro software, you can see the results of the survey carried out as follows:

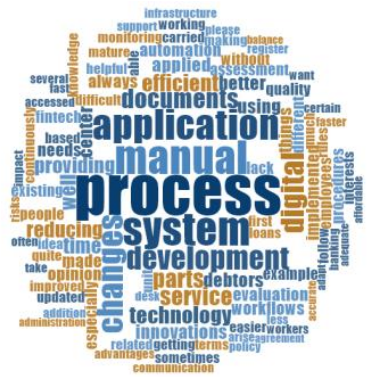

Figure 1. The Main Cause of Inefficiency in PT X 
Based on the results above, it can be seen that the word "process" is the most frequent. From the results above, it can be seen more deeply by looking at the contents of the survey that was carried out.

The results of the analysis found that inefficient processes were caused by four main factors, as in Figure II.

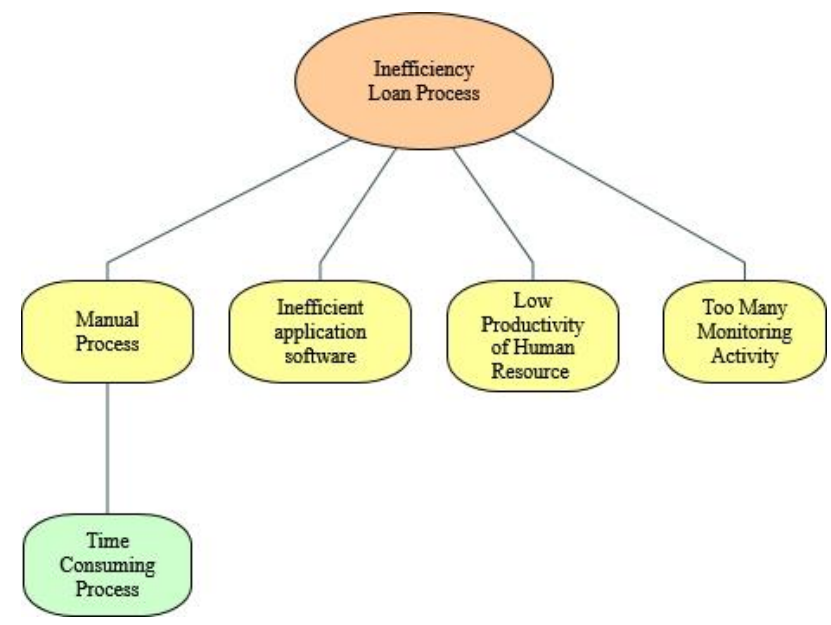

Figure 2. The Cause of Inefficient Loan Process

Figure III shows the causes of manual processes. First, there are hard copy documents, thus the process must be done manually. Second, there are no tools that can help in the document registration process, which makes this process must be done manually. For example, inputting data for calculating service levels is still done manually using MS Excel by staff, thus this process requires consistency and honesty from the staff (Respondent 8, 2019). Finally, there are still many manual work processes.

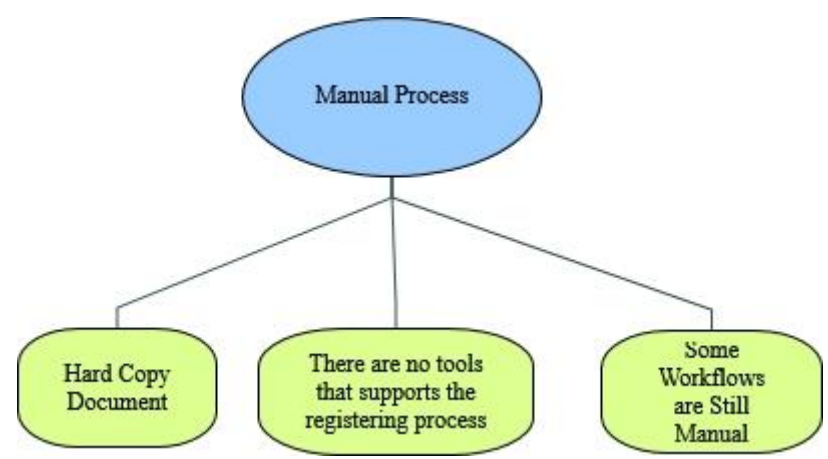

Figure 3. The Cause of Manual Process

Furthermore, Figure IV shows the four items that make the application become inefficient. First, the existing application is not integrated, so there is a process that must be redone because the same data do not appear in other applications. Second, the development of the application itself takes a very long time, thus it cannot support the needs of today's users. Third, there are too many applications used in one process (Respondent 4, 2019). Fourth, the applications are not user-friendly, therefore making it difficult for users.

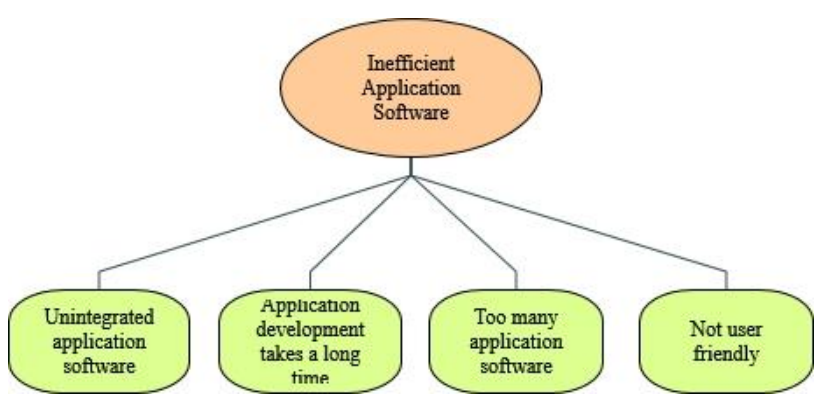

Figure 4. The Cause of Inefficient Application Software

In terms of human resources (Figure V), there are three items that affect the productivity of workers. First, there is a refusal from senior employees when there is a change, which hinders changes from being made by the work unit. Second, there are unbalanced employee workloads among the employees. Third, there is the fear of trying new things, which makes it difficult for employees to develop (Respondent 5, 2019).

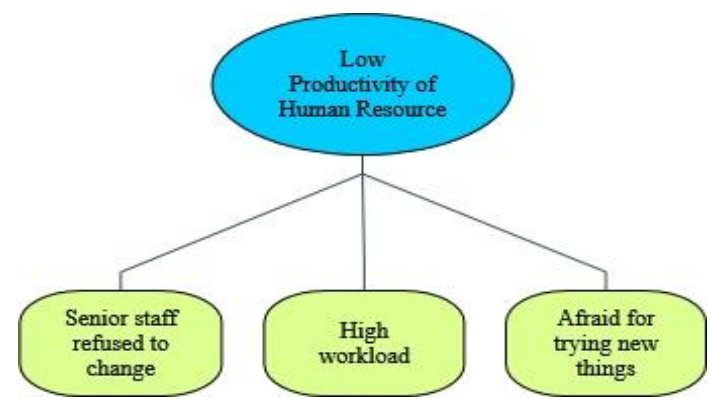

Figure 5. The Cause of Low Productivity in Human Resource

Then, for the monitoring process, which can be seen in Figure VI, employees experience difficulties in carrying out the monitoring process, for example, monitoring the shortage of documents that have not been submitted by the borrower. In addition, the monitoring process is still done manually, by looking at the report, but the format of the report is difficult to read. Thus, there is a risk that the borrower document is incomplete. 


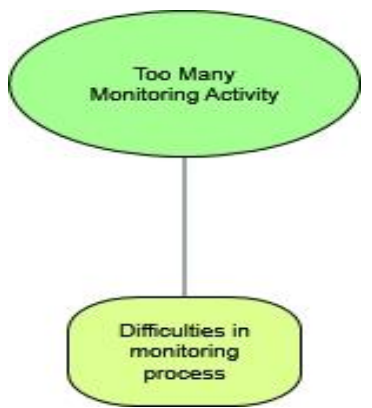

Figure 6. The Cause of Too Many Monitoring Activities

\subsection{Observation}

The observation data were analyzed using descriptive analysis. Observations were made at the head office of a loan work unit at PT X, and the work process was analyzed through a flowchart.

First, when the decision letter is received by the reviewer using the application, the next process is that the reviewer must split the document, but this process is not necessary. However, this process must still be carried out even though this process can be said to be a non-valueadded activity. For that, there is a need to change the application system.

Second, the completeness of the borrower's documents was not fulfilled at the beginning, so that, when the process entered the head office's loan work unit, it had to return to request a document shortage to the borrower. This makes the working process at the head office become inefficient because employees have to wait for the complete documents from the borrower to be able to carry out the process. Constraints faced in the field are that the borrower is sometimes difficult to contact, the borrower is abroad, and the required documents do not exist or have matured so they cannot be used. These are the obstacles faced by the head office loan unit, while employees in this unit are required to fulfill service levels.

Third, in making documents such as credit agreements, borrower statements, and other statements, some processes are still done manually, because the existing applications do not support the entire condition. In addition, this application is not integrated with the data in previous applications, which makes this process semimanual.

Fourth, the process of receiving a shortage of documents from the courier is still done manually by recording in books. The obstacle faced in the field is that this book often does not return for a long time, thus hampering the process of handover of documents. In addition, documents are sometimes lost because they are not recorded in the book.
Fifth, the disbursement process cannot be done with one application. In certain cases, this disbursement process must be done in another application as the initial application cannot be supported or experiences an error. If the process is done in another application, of course it will take longer.

Sixth, data search in the application was difficult because the data are not well organized. In addition, document naming is not consistent, therefore making it difficult for application users who want to see documents to find them. This activity requires a lot of time, especially in searching for documents in the application.

Seventh, the process of storing original documents, such as the original land certificate, original mortgage certificate if the guarantee is in the form of a ship, original documents related to loan, and other original documents, are still carried out manually. The obstacle experienced by this work unit is when conducting a "stock-opname", which can take approximately three months for one area, while in this unit has four regions, which means to do the stock-opname takes approximately one year and this process is carried out every year, thus this process is very time consuming for the original document storage unit.

\subsection{Interview}

The interview data were analyzed using content and thematic analysis. Based on the results of interviews conducted and processed using the word frequency for all responses in NVIVO 12 Pro, the following results are obtained:

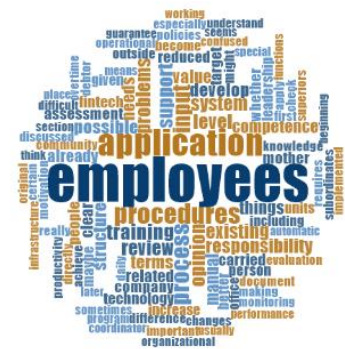

Figure 7. The Cause of Inefficient Process

Based on Figure VII, it can be seen that the word that appears most often is "employees". From this, the content of interviews conducted can be seen more deeply, especially regarding employees. This employee is a resource owned by PT $X$. Based on the interviews conducted, the main problem with employees is the existence of obscurity related to the assessment of performance. The KPI used for employees is sometimes not in accordance with the main job done by the employees. 
In addition, the target given is also sometimes difficult to run by lower-level employees because how to achieve the target is not explained in more detail by the supervisor. Meanwhile, these lower-level employees tend to do operational work, thus this KPI must be able to be implemented by operational level employees. By doing so, employees will not experience difficulties in understanding the KPI given, but still support the main KPI that is owned by the supervisor (Respondent 1, 2019).

Another problem is that senior employees resist change, while junior employees or new employees, even though they do not have much experience, are more proactive (Respondent 4, 2019). Another problem is the lack of even distribution of training quotas and sometimes the training does not really support the job.

Then, based on thematic analysis, the following results are obtained:

Table 1. Thematic Analysis for Each Interviewee

\begin{tabular}{|c|c|c|}
\hline Interviewee & Theme & Sub Theme \\
\hline 1 & Employees & $\begin{array}{ll}- & \text { KPI } \\
- & \text { Training } \\
- & \text { Senior employees } \\
& \text { resist to change }\end{array}$ \\
\hline 2 & Application & $\begin{array}{ll}- & \text { Too many } \\
& \text { applications } \\
- & \text { Unintegrated } \\
\text { - } & \text { Less user-friendly }\end{array}$ \\
\hline 3 & Procedure & $\begin{array}{llr}\text { - } & \text { No procedure for } \\
\text { special cases } & \\
\text { - } & \text { There is no } \\
\text { uniformity } & \text { in } \\
\text { carrying out the } \\
\text { procedure }\end{array}$ \\
\hline 4 & Process & $\begin{array}{ll}- & \text { Manual }\end{array}$ \\
\hline
\end{tabular}

Based on Table 1, the first interviewee focuses more on employee-related issues, especially related to job evaluation systems where KPIs or targets given to each employee have some unclear points, making it difficult for employees to understand their targets. In addition, at the time of performance appraisal, the system tends to be more closed, meaning that employees also do not know why they get that performance score.

This makes employees less motivated to improve their performance because they have a mindset that the score given will range only to certain numbers in the following year. In the McKinsey 7S model one is staff; it can be said that PT X, especially in the loan work unit, still has not managed this staff side effectively. For this reason, employees must be one of the main focuses of PT X to be improved so that the performance of each employee can be maximized.
In addition, senior employees tend to be more resistant to new changes or innovations. This, of course, becomes a barrier for work units to be developed. For this reason, the role of a supervisor becomes very important here. However, the tone at the top is still lacking, which makes senior employees also prefer to be resistant to changes.

Another item that makes these employees not have maximum performance is that many processes are still run manually, which also makes employees have to work more to complete a job and ultimately makes employees also feel the workload given is not balanced.

Training given to employees is also not evenly distributed, thus the knowledge is less evenly distributed. This needs to be a concern too. The McKinsey $7 \mathrm{~S}$ model also has the dimension of skills, thus this is one of the factors that must be considered by management to improve the employees productivity.

From the results of the second interviewee, the main focus is on the application, or, when viewed from the McKinsey 7S model, the system dimension. This means that the system within this work unit is still not optimal. This can be seen from several items, especially those relating to the application.

Some items that make the application even less optimal are that the application cannot cover the entire process. In addition, there are too many applications that have not been fully integrated, which creates a repetitive process and becomes an activity that has no value. In addition, some applications are still less user-friendly, making it difficult for users to operate them.

For Interviewees 3, the main focus is on procedures, where the procedure is related to the system dimensions in the McKinsey 7S model. The procedures in this work unit are still not uniform, and there are procedures that have not covered a number of special cases. For this reason, the existing procedure must be able to cover all the problems that occur in the work unit. In addition, this must also be communicated thoroughly to all employees in the work unit.

For Interviewee 4, the main focus is the same as the results of the survey carried out, namely from the process side, where the work process exists even though there is already an application, but there are still many manual processes that make the control weak. Thus, the loan work unit at PT X must improve its work process, so that the running process can be more efficient. 


\subsection{Factors that Make the Process Inefficient}

Based on the findings above, it can be concluded that there are several causes of the lending process to borrowers in PT X becoming inefficient:

- Viewed from the side of the process or work flow, there are several problems that occur that cause inefficiency.

- An inappropriate employee evaluation system tends to make employees confused and ultimately demotivated.

- There is resistance from senior employees who hinder the implementation of new innovations or changes in work systems.

- Too many applications are used and there are some parts that are not integrated.

- There are still many processes carried out manually, which requires a long processing time.

- Existing procedures have not been carried out uniformly among employees, which makes a difference in work processes between units.

\subsection{Suggestion Future Research}

Based on contingency theory, there is no right decision that can be taken by the company, but the company must look at various factors to make that decision (Otley 1980). Similarly, in the case in PT X, there was a problem that the work process of the loan work unit at the head office did not work effectively and efficiently, especially for lending to SMEs.

For this reason, there needs to be an improvement in the work process at PT X. The following are suggestions based on the McKinsey $7 \mathrm{~S}$ model:

Table 2. Suggestions based on McKinsey 7S

\begin{tabular}{|l|l|}
\hline Dimension & Suggestion \\
\hline Structure & $-\quad \begin{array}{l}\text { Formalizing, related to procedures and } \\
\text { policies so that, when the structure changes } \\
\text { to centralization, there is a uniformity of } \\
\text { work processes for all employees }\end{array}$ \\
\hline Strategy & $-\quad \begin{array}{l}\text { Focus more on digitalization, for example } \\
\text { by making loan applications online and } \\
\text { directly integrated with internal } \\
\text { applications in the loan work unit. }\end{array}$ \\
\hline System & $-\quad \begin{array}{l}\text { Integration of existing applications so that } \\
\text { there is no recurring process } \\
\text { In the long term, one end-to-end } \\
\text { application can be made to make it easier } \\
\text { for employees } \\
\text { Eliminating the manual processes, such as } \\
\text { handover of documents that still need to be } \\
\text { recorded in the book can be replaced by } \\
\text { using MS Access or creating a small app } \\
\text { for the handover process }\end{array}$ \\
\hline
\end{tabular}

\begin{tabular}{|l|ll|}
\hline & - & $\begin{array}{l}\text { Use of radio frequency identification in } \\
\text { storing documents in the repertoire, so as to } \\
\text { speed up the time of stock taking }\end{array}$ \\
\hline Style & - & $\begin{array}{l}\text { Improve communication to subordinates, so } \\
\text { that employees have clarity on their job and } \\
\text { KPI or targets that must be completed }\end{array}$ \\
\hline Staff & - & $\begin{array}{l}\text { Create KPIs that are easy to understand and } \\
\text { run by employees } \\
\text { More evenly distribute training schedules }\end{array}$ \\
\hline Skills & - & $\begin{array}{l}\text { Periodic sharing of knowledge, so that the } \\
\text { competencies of employees do not } \\
\text { experience inequality }\end{array}$ \\
\hline $\begin{array}{l}\text { Superordinate } \\
\text { Goals }\end{array}$ & - & $\begin{array}{l}\text { Communicate regularly related to the goals } \\
\text { to be achieved and the values that must be } \\
\text { carried out by all levels in the company }\end{array}$ \\
\hline
\end{tabular}

\section{CONCLUSIONS AND IMPLICATIONS}

The problem that occurs in this study is that the productivity of credit staff in PT $\mathrm{X}$ is very low, i.e. 11 times lower than its best practices. For this reason, this research was conducted with the aim of finding the causes of these problems and providing recommendations. The results of this study are that PT X and banks must look at their internal processes in more detail; in this case, the processing of loans submitted by borrowers, where the manual process is still found. In addition, the applications used are still not integrated with each other, thus making repeated work processes. Then, from the employee side, the target or KPI provided is unclear, so that employees tend to be demotivated.

Thus, the expected implications is that banks, especially for loan division, should improve their internal process so that loan division can optimize their time and process in giving loan to customer. With the improvement in loan process from the bank, it expected to increase the customer satisfaction and in the end the bank will not lose their competitiveness. In addition, banks should consider using a technology to make the process more efficient, e.g. using big data analysis to capture customer needs in detail, using artificial intelligence to improve their service to customers, or other advanced technology. For human resource aspect, management should review the KPI given to the employees so that they can understand what they can contribute to achieve the division or company goals. It is important because without a clear and understandable KPI, employees will lose direction and eventually their motivation.

\section{RESEARCH LIMITATIONS}

The limitation of this study is the limited time in conducting research. In addition, this study also does not involve other financial service providers. For this reason, the proposal for further research is to expand the object of 
research so that the results obtained will better capture other problems that may arise in other companies. In addition, the recommendations given can be further multiplied, so that it can provide an alternative for companies in providing financial services.

\section{REFERENCES}

[1] Cox, AM 2018, 'Extending McKinsey's 7S model to understand strategic alignment in academic libraries', Emerald Publishing Limited.

[2] Denzin, NK 1978, The research act, 2nd edn.

[3] Ellet, W 2007, The case study handbook how to read, discuss, and write persuasively about cases, Harvard Business School Press, Boston, Massachusetts.

[4] Gao, F 2016, 'Reducing customer waiting time of commercial banking', Proquest.

[5] Hansen, DR \& Mowen, MM 2015, Cornerstones of cost management, Cengage Learning, United States.

[6] Jick, TD 1979, 'Mixing qualitative and quantitative methods: Triangulation in action', Johnson Grad. Sch. Manag. Cornell Univ.

[7] Kaplan, RS \& Cooper, R 1998 Cost and effect: using integrated cost systems to drive profitability and performance, Harvard Business School.

[8] Morse, J 1991, 'Approaches to qualitative-quantitative methodological triangulation', Nursing Research, vol. 40.

[9 ]Nicholson, GJ 2003, 'A framework for diagnosing board effectiveness', Sch. Bus. Univ. Queesl.

[10] Otley, D 1980, 'The contingency theory of management accounting and control', Management Accounting Research.
[11] Otoritas Jasa Keuangan, Penyelenggara Fintech Terdaftar di OJK per December 2018, 2019. [Online]. Available: https://www.ojk.go.id/id/beritadan-

kegiatan/publikasi/Documents/Pages/PenyelenggaraFintech-Terdaftar-di-OJK-per-8-April-

2019/Penyelenggara Fintech Terdaftar April 2019.pdf. [Accessed: 23-Apr-2019].Tassakhori, A \& Creswell, JW 2008, 'Mixed methodology across disciplines', Journal of Mixed Methods Research.

[12] Parker, L 2005, 'Social and environmental accountability research: A view from the commentary box'.

[13] Pindyck, RS \& Rubinfeld, DL 2013 Microeconomics, Pearson, United States.

[14] Ramcharran, H 2017, 'Bank lending to small business in India: Analyzing productivity and efficiency', The Quarterly Review of Economics and Finance, vol. 65, pp. 16-24.

[15] Rossman, GB \& Wilson, BL 1985, 'Combining quantitative and qualitative methods in a single largescale evaluation study'.

[16] Schonfeld, IS \& Farrell, E 2010, 'Qualitative methods can enrich quantitative research on occupational stress: An example from one occupational group', Research in Occupational Stress and Well Being.

[17] Waterman, RH, Peters, TJ, \& Phillips JR 1980, 'Structure is Not Organization', Business Horizons.

[18]Yin, RK 2009 Case study research design and method, $4^{\text {th }}$ edn, Sage Publications, Inc., United States. 